\title{
WYKAZ PRAC DYPLOMOWYCH $Z$ ANTYKU CHRZEŚCIJAŃSKIEGO UKOŃCZONYCH W NIEKTÓRYCH POLSKICH OŚRODKACH NAUKOWYCH W 1999 ROKU
}

\section{KATOLICKI UNIWERSYTET LUBELSKI}

\section{A. WYDZIAE TEOLOGICZNY}

\section{Prace doktorskie}

1. Ks. Galant Wiesław, Elekcje biskupów rzymskich do końca IV wieku (obrona 19 V 1999; promotor - ks. bp prof. dr hab. J. Śrutwa, recenzenci: ks. prof. dr hab. E. Stanula, ks. dr hab. J. Pałucki).

2. Ks. Majewski Dariusz, Działalność papieża Wigiliusza w Konstantynopolu (547-555) (obrona 10 XII 1998; promotor - ks. bp prof. dr hab. J. Śrutwa, recenzenci: ks. prof. dr hab. E. Stanula, ks. prof. dr hab. B. Kumor).

\section{Prace magisterskie}

1. Bryła Dariusz, Seminarium patrystyczne w KUL (1993-1998) (prom. ks. prof. F. Drączkowski).

2. Gotowicka Aleksandra, Starożytne formuty echematyczne jako formuty intonacyjne choratu gregoriańskiego (prom. ks. prof. J. Ścibor).

3. Kołkowska Agnieszka, Mistagogiczny charakter sakramentów inicjacji chrześcijańskiej $w$ „De mysteriis” $i$ „De sacramentis” św. Ambrożego (prom. ks. dr K. Gurda, Kielce).

4. Kot Piotr, Istota kapłaństwa wedtug św. Augustyna (prom. ks. prof. Cz. Bartnik).

5. Kowal Katarzyna, Problem modelu chrystologii antiocheńskiej w polskiej teologii posoborowej (prom. ks. dr hab. J. Szymik).

6. Kwietniewski Dariusz, Środki zbawienia w ujęciu apoftegmatów Ojców Pustyni (prom. ks. prof. dr hab. J. Krasiński).

7. Labudda Marek, Życie ludzkie w świetle katechez św. Jana Chryzostoma (prom. ks. prof. A. Eckmann).

8. Mamczak Iwan, Teologia chrztu w świetle katechez św. Jana Chyryzostoma (prom. ks. prof. J. Kopeć). 
9. Moszczyńska Edyta, Program doskonalenia chrześcijańskiego w koncepcji mnichów syryjskich na podstawie „Dziejów miłości Bożej” Teodoreta z Cyru (prom. ks. dr K. Gurda, Kielce).

10. Ordon Piotr, ,Laudate Dominum” w „Enarrationes in Psalmos” św. Augustyna (prom. ks. prof. F. Drączkowski).

11. Pańkiw Iwan, Koncepcja życia moralno-duchowego według św. Bazylego Wielkiego (329-379) (prom. ks. dr S. Mojek).

12. Rejak Sebastian, Eschatologia nadziei w pismach Izaaka Syryjczyka (prom. ks. prof. W. Hryniewicz).

13. Wysocki Marek, Nauka Orygenesa o wierze w jego „Komentarzu do Listu św. Pawła do Rzymian” (prom. ks. prof. F. Drączkowski).

14. Zarosa Ewelina, Teologia drogi wtajemniczania chrześcijańskiego w katechezach mistagogicznych św. Ambrożego (prom. ks. prof. J. Pałucki).

15. Żuraw Andrzej, Życie moralne chrześcijan w świetle „Homilii do Psalmów” św. Bazylego Wielkiego (ks. prof. J. Nagórny).

16. Żyrkowa Anna, Ostateczny cel dążen ludzkich. Studium porównawcze koncepcji św. Augustyna z Hippony i św. Tomasza z Akwinu (prom. ks. prof. J. Pałucki).

\section{B. WYDZIAŁ HUMANISTYCZNY}

\section{Prace magisterskie}

Katedra Literatury Wezesnochrześcijańskiej - ks. prof. dr hab. A. Eckmann

1. Bobel Renata, Aurelius Augustinus, „De sancta virginitate” 1. 1 - 30. 30. Wstęp, przektad, komentarz.

2. Bojko Honorata, Aurelius Augustinus, „De sancta virginitate” capita 31.31 - 56. 57. Wstęp, przektad, komentarz.

3. Hase Joanna, Motywy antyczne w poezji Romana Brandstaettera.

4. Majcher Monika, Aurelius Augustinus, Epistola 185. „De correctione Donatistarum liber". Wstęp, przekład, komentarz.

5. Ziętal Magdalena, Aurelius Augustinus, Epistola 187. „De praesentia Dei”. Wstęp, przekład, komentarz.

\section{Katedra Filologii Klasycznej Lacińskiej - ks. prof. dr hab. H. Wójtowicz}

1. Banaś Monika, Ambrosius Aurelius, „De virginitate”. Wstęp, przekład, komentarz.

2. Ks. Jędrzejewski Przemysław, Ambrosius Aurelius, „De Helia et ieiunio”. Wstęp, przekład, komentarz.

3. Kiernozek Monika, Ambrosius Aurelius, „De interpellatione Job et David”. Wstęp, przekład, komentarz.

4. O. Walkowiak Arkadiusz Natalis, Ambrosius Aurelius, „Exhortatio virginitatis". Wstęp, przekład, komentarz. 


\title{
II. AKADEMIA TEOLOGII KATOLICKIEJ W WARSZAWIE
}

\section{A. WYDZIAŁ KOŚCIELNYCH NAUK HISTORYCZNYCH I SPOEECZNYCH}

\section{Katedry Patrologii Greckiej i Lacińskiej}

\author{
Prace magisterskie
}

1. Dmitruk Marek, Zagadnienie wolności woli człowieka w ,Homiliach na List do Rzymian” św. Jana Chryzostoma (prom. ks. prof. W. Myszor).

2. Drewnowski Wojciech, Elementy prawodawstwa rzymskiego w pismach apologetycznych Tertuliana (prom. ks. prof. E. Stanula).

3. Malińska Monika, Zawody związane $z$ widowiskami $w$ ocenie Tertuliana (prom. ks. prof. E. Stanula).

4. Mendelova Edyta, Cnoty w ujęciu Jana Kasjana (prom. ks. prof. E. Stanula).

5. Nowosińska Barbara, Życiowe powołanie kobiety $w$ listach św. Hieronima (prom. ks. prof. E. Stanula).

6. Przyszychowska Marta, J 19, 25-27 w interpretacji łacińskich Ojców Kościota (prom. ks. prof. E. Stanula).

7. Wilczyńska Justyna, Drugie małżeństwo według Jana Chryzostoma (prom. ks. prof. W. Myszor).

8. Zimka Karolina, Życie codzienne mnichów na podstawie starożytnych regut monastycznych Kościoła Zachodniego (prom. ks. dr T. Kołosowski).

\section{PAPIESKA AKADEMIA TEOLOGICZNA W KRAKOWIE}

\section{A. WYDZIAŁ TEOLOGICZNY}

\section{Katedra Patrologii i Historii Dogmatu - ks. prof. dr hab. E. Staniek}

$$
\text { Prace magisterskie }
$$

1. Babiarz G., Bohaterki życia ascetycznego. Studium „Opowiadań dla Lausiosa" Palladiusza.

2. Jamroziński W., „Ojcze, święć się imię Twoje” - w ujęciu wschodnich i zachodnich Ojców Kościoła.

3. Kiszczak M., „Ojcze, odpuść nam nasze winy, jako i my odpuszczamy naszym winowajcom" - w ujęciu św. Augustyna.

4. Króżel K., Rzeczy ostateczne i ich wpływ na życie człowieka. Studium pism ascetycznych i homilii św. Bazylego Wielkiego.

5. Smyrak M., Homiletyczne zasady interpretacji Pisma św. wedtug św. Augustyna. 
6. Sordyl K., Bóg i tajemnica człowieka. Studium ,Wykładu wiary prawdziwej" Jana z Damaszku.

7. Woźniak R., Teologiczne podstawy kultu ikon i świętych. Studium „Wykładu wiary prawdziwej" Jana z Damaszku.

8. Wojdyła M.F., Miłosierdzie Boga i ludzi. Studium „Mów” Grzegorza Teo$\log a$ (Instytut Teologiczny w Częstochowie).

\section{WYDZIAŁ FILOZOFICZNO-TEOLOGICZNY XX. JEZUITÓW W KRAKOWIE}

\section{Katedra patrologii - ks. prof. dr hab. H. Pietras}

Prace magisterskie

1. Kopiec Ewa, Obraz Boga w człowieku a nawrócenie w nauczaniu św. Augustyna (,O Trójcy Świętej” VIII-XIV).

2. Kufta Dariusz, Rola kultury helleńskiej w wychowaniu do postaw religijnych w ujęciu Klemensa Aleksandryjskiego, na podstawie jego „Zachęty do Greków".

3. Kwaśniewska Urszula, Elementy Bożej pedagogii w homiliach Orygenesa do Księgi Wyjścia.

4. Skrzypek Jadwiga, Intencjonalność świata. Wpływ Platona na Orygenesa.

5. Zarzeczny Rafał, „Agapetos” jako tytut Chrystusa preegzystującego $w$,Ascensio Isaiae” (Bobolanum, Warszawa).

Prace doktorskie

1. Grodecki Tomasz, Jedność i różnica. Koncepcja ousia i hypostasis w „De differentia essentiae et hypostaseos” św. Grzegorza z Nyssy i jej genezaprom. ks. prof. H. Pietras.

2. Wnętrzak Teresa, Znaczenie wybranych pojęć filozoficzno-politycznych w myśli historiozoficznej św. Augustyna na podstawie „De civitate Dei” (WSP, Kraków).

\section{WYDZIAE TEOLOGICZNY UAM W POZNANIU}

Prace magisterskie
A. Wyższe Seminarium Duchowne w Poznaniu - ks. prof. dr hab. B. Częsz
1. Berlak Alfred, Krew męczennika w interpretacji Tertuliana iśs. Cypriana.
2. Klupi Jarosław, Chrystus Odkupiciel człowieka w nauczaniu św. Bazylego. 
3. Kubiak Tomasz, Teologia polityczna w pismach św. Leona Wielkiego.

4. Matuszek Tomasz, Nadzieja nowego życia w ujęciu św. Jana Chryzostoma.

5. Michalak Marek, Nauka o Krwi Chrystusa u Ojców Kapadockich.

6. Zbączyniak Grzegorz, Maryja w nauczaniu św. Jana Damasceńskiego.

B. Wyższe Seminarium Duchowne w Gnieźnie - ks. dr B. Czyżewski

1. Balcer Jarosław, Wskazania moralne dotyczace matzenstwa w kazaniach św. Cezarego z Arles.

2. Grygiel Jakub, Postawa św. Cypriana wobec apostatów i heretyków w jego listach.

3. Lewandowski Sebastian, Sobory Powszechne okresu patrystycznego w dokumentach papieskich $X X$ wieku.

4. Pacanowski Maciej, Nauka o Eucharystii w pismach Orygenesa.

5. Radowski Marek, Typologiczne przedstawienie Chrystusa i Kościoła w homilii „Peri Pascha” Melitona z Sardes.

6. Nurski Robert, Argumentacja filozoficzna na rzecz monoteizmu u wybranych pisarzy II i III wieku (prom. dr L. Gładyszewski, 1995).

7. Orchowicz Radosław, Struktury hierarchiczne pierwszych gmin chrześcijanskich w świetle listów św. Ignacego Antiocheńskiego (prom. ks. dr L. Gładyszewski, 1994).

\section{WYDZIAE TEOLOGICZNY UNIWIERSYTETU OPOLSKIEGO}

\section{Katedra Historii Kościoła i Patrologii}

Prace magisterskie

1. Dobosz Grzegorz, Miłość jako zasada życia monastycznego według „Regut" św. Bazylego Wielkiego (prom. ks. dr N. Widok).

2. Domowicz Brygida, Kobiety chrześcijańskie w „Historii kościelnej” Euzebiusza z Cezarei (prom. ks. prof. K. Dola).

3. Jaśkiewicz Tadeusz, Pokuta w nauczaniu Tertuliana (prom. ks. dr N. Widok).

4. Kunas Irena, Troska pasterska św. Cypriana o praktykę wiary chrześcijan $w$ świetle jego listów (prom. ks. dr N. Widok).

5. Nokiel Małgorzata, Świadectwa Ojców afrykańskich o Eucharystii i sposobie jej sprawowania w okresie prześladowań Kościoła w Imperium Rzymskim (prom. ks. prof. K. Dola).

6. Zwarycz Mariusz, Recepcja „Etyk” Arystotelesa w „Stromatach” Klemensa Aleksandryjskiego (prom. ks. dr N. Widok). 


\section{PAPIESKI WYDZIAŁ TEOLOGICZNY WE WROCŁAWIU}

$$
\text { Prace magisterskie }
$$

1. Jaworski Franciszek, Pokuta starochrześcijańska w świetle publikacji teologicznych po Soborze Watykańskim II (prom. ks. prof. A. Młotek).

2. Kempa Grzegorz, Nauka o celibacie kapłańskim w listach $i$ wypowiedziach papieża Syrycjusza (384-399) (prom. ks. dr hab. Z. Lec).

\section{WYŻSZE ŚLĄSKIE SEMINARIUM DUCHOWNE W KATOWICACH}

$$
\text { Prace magisterskie }
$$

1. Brach Ireneusz, Testimonia w, Wykładzie nauki apostolskiej” św. Ireneusza (prom. ks. prof. W. Myszor, 1997).

2. Nakonieczny Rafal, Officium w „De officiis Cycerona” $i$,De officiis ministrorum” św. Ambrożego (prom. ks. prof. W. Myszor, 1999).

3. Zych Grzegorz, Biskup wobec władzy państwowej w listach św. Bazylego Wielkiego (prom. ks. prof. W. Myszor, 1997).

\section{WYŻSZE SEMINARIUM DUCHOWNE W KIELCACH}

\section{Prace magisterskie}

1. Picheta Mariusz, Obrazy męczeństwa $w$ opisach martyrologicznych św. Ambrożego (prom. ks. dr K. Gurda).

2. Szlenk Grzegorz, Wdowieństwo w „De viduis” św. Ambrożego (prom. ks. dr K. Gurda).

3. Kołkowska Agnieszka, Mistagogiczny charakter sakramentów inicjacji chrześcijańskiej $w$ „De mysteriis” $i$ „De sacramentis” św. Ambrożego (prom. ks. dr K. Gurda, obrona WTKUL).

4. Moszczyńska Edyta, Program doskonalenia chrześcijańskiego w koncepcji mnichów syryjskich na podstawie „Dziejów mitości Bożej” Teodoreta z Cyru (prom. ks. dr K. Gurda, obrona WTKUL).

\section{WYŻSZE SEMINARIUM DUCHOWNE W ŁODZI (OBRONIONE W ATK)}

$$
\text { Prace magisterskie (prom. ks. dr J. Słomka) }
$$

1. Adamczewski Maciej, Pozabiblijne źródła Objawienia według św. Justyna.

2. Blicharska Anna, Świętowanie Paschy w świetle wybranych pism Ojców Kościoła (Melitona $z$ Sardes, Orygenesa, Efrema, Jana Chryzostoma). 
3. Gębicka Monika, Działanie Ducha Świętego w życiu chrześcijanina na podstawie „Objaśnienia Psalmów” św. Augustyna.

4. S. Igowska Bożena, Męczeństwo w świetle życia i pism św. Justyna.

5. Kowalczyk Małgorzata, Śmierć i rzeczy ostateczne czlowieka $w$ świetle pism św. Ambrożego.

6. Pawlak Albina, Ideat biskupa wedtug św. Ambrożego.

7. Ryndak Jadwiga, Duch Święty w dzietach św. Bazylego.

8. Sapała Halina, Eucharystia według teologii św. Augustyna.

\title{
XI. ARCYBISKUPIE WYŻSZE SEMINARIUM DUCHOWNE W SZCZECINIE
}

$$
\text { Prace magisterskie }
$$

Halec Marek, Ideat życia ascetycznego reprezentowanego przez św. Antoniego Pustelnika w, „Vita Antonii” św. Atanazego (prom. ks. dr S. Czubak).

\section{INSTYTUT TEOLOGICZNY W TARNOWIE (ODDZIAE PAT)}

\section{Prace magisterskie}

1. Cyz P., Specyfika i sens ascezy syryjskich Ojców Pustyni w świetle „Dziejów miłości Bożej" Teodoreta z Cyru (prom. ks. dr hab. A. Żurek).

2. Gawle J., Aurelius Augustinus, „De mendacio”. Wstęp, przekład, komentarz (prom. ks. dr hab. A. Żurek).

3. Jarek B., Ideat wychowania w świetle „De catechizandis rudibus” św. Augustyna (prom. ks. dr. S. Sojka).

4. Onze C.M., Les problèmes de la Trinité au IV siècle. Controverse de Saint Basile et Eunome (prom. ks. dr hab. A. Żurek).

5. Wojtusik-Pabian A., Problematyka dydaktyczno-pedagogiczna w wybranych pismach św. Augustyna (prom. ks. dr A. Solak).

\section{WYŻSZA SZKOŁA PEDAGOGICZNA - INSTYTUT W RZESZOWIE}

\author{
Prace magisterskie
}

1. Gapik Witold, Ad bestias. Prawne aspekty prześladowań chrześcijan w I-III wieku. (prom. prof. L. Morawiecki). 
XIV. INSTYTUT HISTORII - HISTORA STAROŻYTNA UMCS W LUBLINIE

$$
\text { Prace magisterskie }
$$

1. Kulbaka Artur, Polityka Cesarstwa Rzymskiego wobec chrześcijan do końca panowania Nerona (prom. prof. L. Morawiecki).

2. Wiśniewski Radomir, Tradycja potopu w literaturze starożytnego Wschodu $i$ w mitach greckich (prom. prof. L. Morawiecki).

Zebrał i opracował Ks. Stanisław Longosz 